\title{
Analysis of glacier facies using satellite techniques
}

\author{
RICHARD S. WILLIAMS, JR, \\ U.S. Geological Survey, 914 National Center, Reston, Virginia 22092, U.S.A. \\ DOROTHY K. HALL \\ National Aeronautics and Space Administration, Hydrological Sciences Branch \\ (Code 974), Goddard Space Flight Center, Greenbelt, Maryland 20771, U.S.A. \\ CARL S. BENSON \\ Geophysical Institute, University of Alaska, Fairbanks, Alaska 99775, U.S.A.
}

\begin{abstract}
The different snow and ice types on a glacier may be subdivided according to the glacier-facies concept. The surficial expression of some facies may be detected at the end of the balance year by the use of visible and near-infrared image data from the Landsat multispectral scanner (MSS) and thematic mapper (TM) sensors. Ice and snow can be distinguished by reflectivity differences in individual or ratioed TM bands on Brúarjökull, an outlet glacier on the northern margin of the Vatnajökull ice cap, Iceland. The Landsat scene shows the upper limit of wet snow on 24 August 1986. Landsat-derived reflectance is lowest for exposed ice and increases markedly at the transient snow line. Above the slush zone is a gradual increase in near-infrared reflectance as a result of decreasing grain-size of the snow, which characterizes drier snow. Landsat data are useful in measuring the areal extent of the ice facies, the slush zone within the wet-snow facies, the snow facies (combined wetsnow, percolation and dry-snow facies), and the respective positions of the transient snow line and the slush limit. In addition, fresh snowfall and/or airborne contaminants, such as soot and tephra, can limit the utility of Landsat data for delineation of the glacier facies in some cases.
\end{abstract}

\section{INTRODUCTION}

The ablation area and the accumulation area of a glacier are separated by the equilibrium line. This is the line across a valley or outlet glacier, or an irrregular line roughly parallel to the margin of an ice cap or ice sheet, where the net mass balance for the glacier equals zero. For many valley and outlet glaciers in temperate climates, the position of the snow line (firn limit) at the end of an average mass-balance year represents the approximate location of the equilibrium line. For more polar glaciers, however, a superimposed ice zone exists between the snow line (firn line) and the equilibrium line. In this zone, ice has formed from water percolating through the wet snow and refrozen on the underlying glacier ice (Wakahama and others, 1976; Paterson, 1981). In these cases the equilibrium line is displaced down-glacier from the snow line (firn line). The surficial expression of a glacier changes throughout the year in response to changing meteorological conditions, especially the type and amount of precipitation and air temperature. The use of satellite data enables some of these changes to be observed and measured.

Although the annual mass balance of a glacier is normally determined from direct field or aerial measurements and observations, by photogrammetric, hydrological or reconnaissance methods (Paterson, 1981), the cost and effort of acquiring the data have meant that massbalance measurements are done on an annual basis for only a few glaciers. Meier (1984) was able to find only 25 glaciers worldwide that had mass-balance and volumechange data available for part or all of the past 50 years. The global coverage provided by satellites provides an opportunity for development of methods for measuring the mass balance of the Earth's glaciers.

After the first Landsat satellite was placed into orbit in July 1972, remotely sensed data have been assessed by various investigators for their application to the determination of glacier mass balance, beginning with Krimmel and Meier (1975) and Østrem (1975). Although the multispectral scanner (MSS) and thematic mapper (TM) sensors are useful, research has shown that many factors 


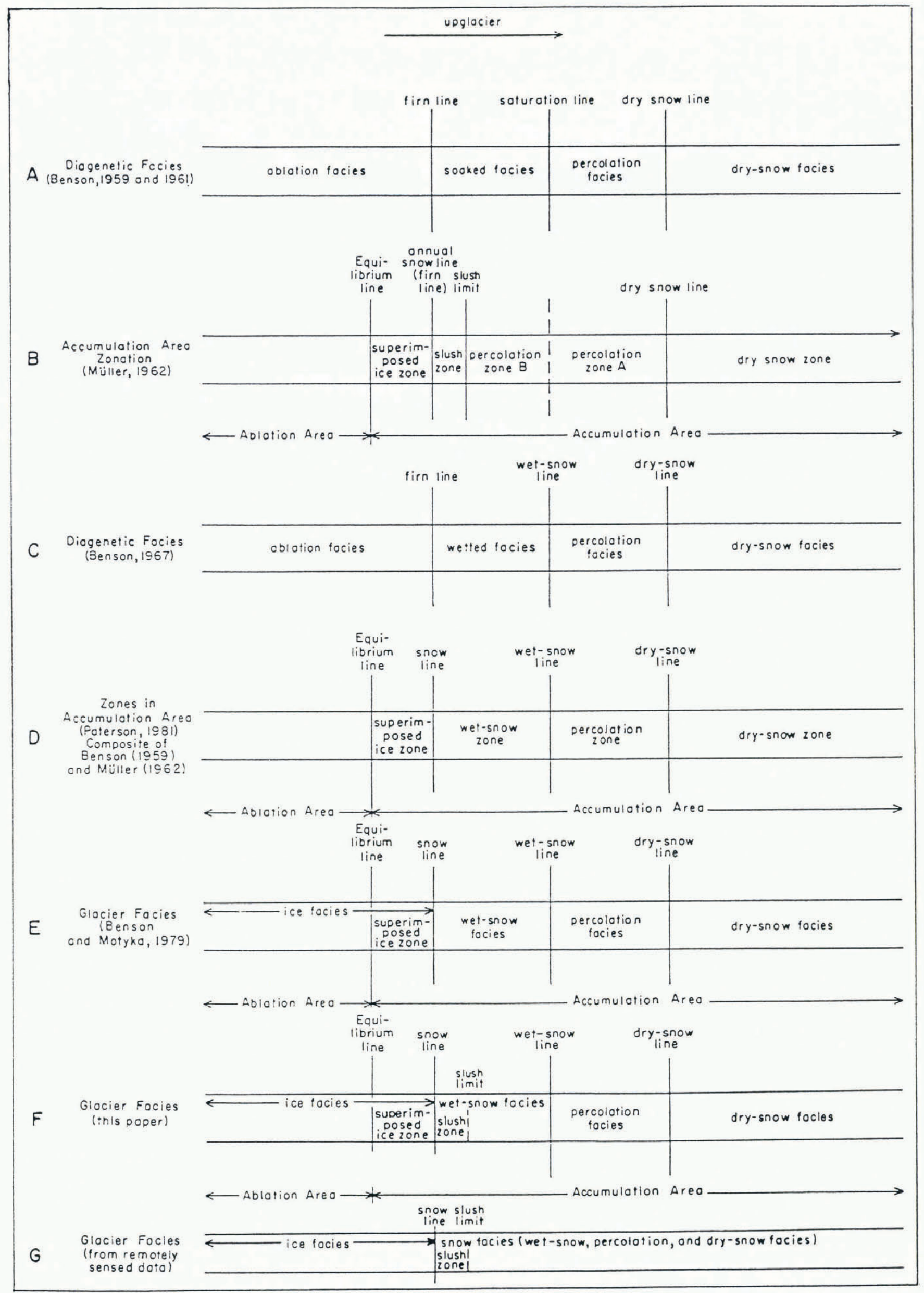

Fig. 1. Schematic comparison of the evolution of the glacier-facies concept developed by (A) Benson (1959, 1961); (B) Müller (1962); (C) Benson (1967); (D) composite of Benson (1959) and Müller (1962) by Paterson (1981); (E) Benson and Motyka (1979); (F) this paper; and $(G)$ from remotely sensed data, this paper. 


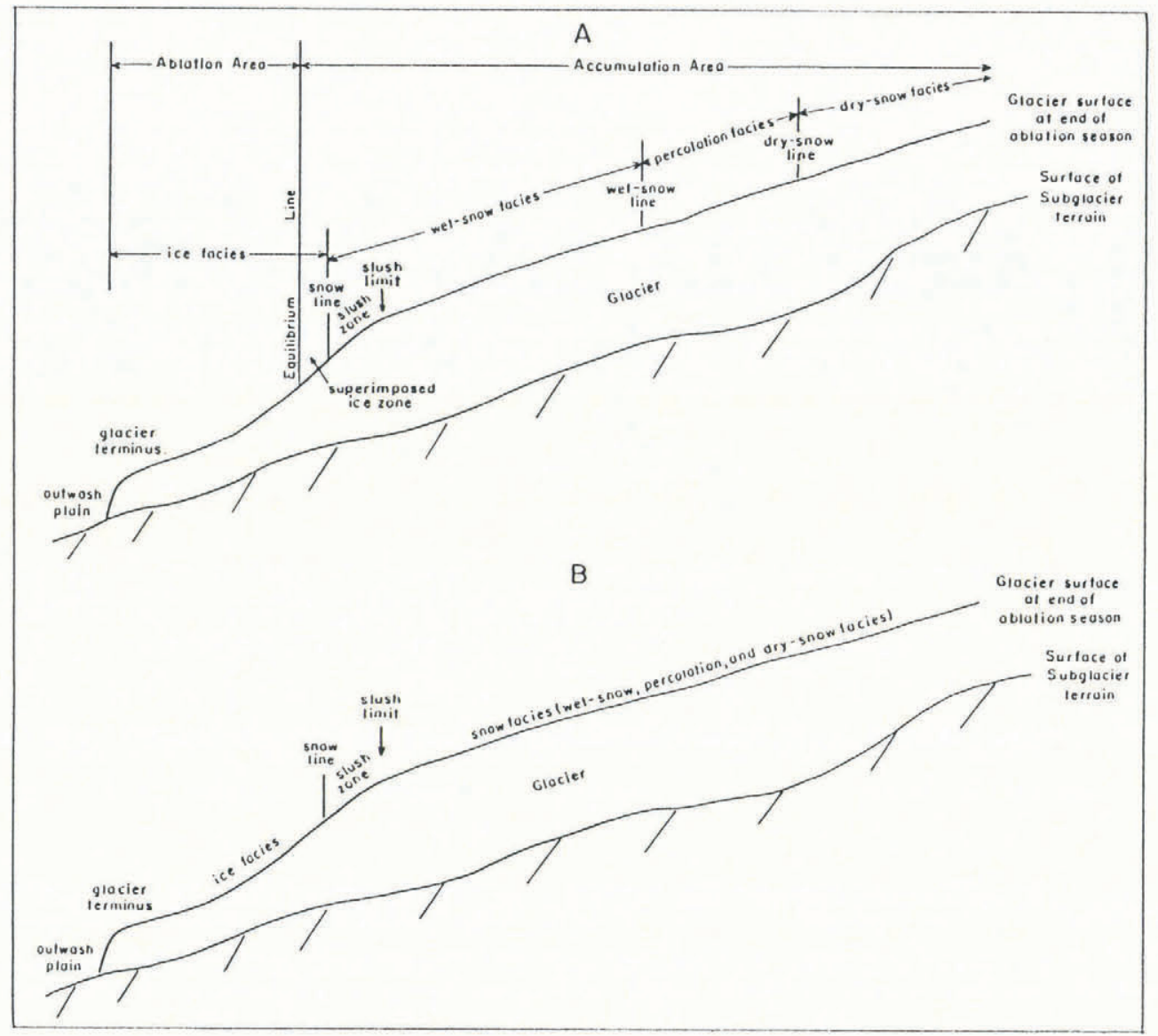

Fig. 2. Cross-section of a glacier showing glacier facies at the end of the balance year. A: from glaciological field observations. B: from spectral-reflectance measurements from satellite sensors.

can complicate the determination of glacier mass balance when data from these two instruments are used.

In this paper, we address the physical mechanisms by which some of the glacier facies may be sensed as well as conditions which complicate the detection of glacier facies by Landsat remote-sensing techniques. Our analysis focuses on Brúarjökull, a surge-type outlet glacier from the northern margin of the Vatnajökull ice cap, Iceland. We determined which glacier facies of those described by Benson (1959, 1961) and Müller (1962) (Fig. 1) could be differentiated using the Landsat TM sensor on the basis of spectral reflectance of Brúarjökull.

\section{DEVELOPMENT OF THE GLACIER-FACIES CONGEPT}

The concept of glacier facies was first developed by Benson $(1959,1961,1962)$ from field observations on the western margin of the Greenland ice sheet from 1952 to 1955. Benson's original concept, called "diagenetic facies" (Benson, 1959) (Fig. 1A), was modified by Müller (1962) (Fig. 1B), whose work was based on examination of glaciers on Axel Heiberg Island, Northwest Teritories, Canada. The development by Benson and Müller of the glacier-facies concept was a refinement of Ahlmann's (1935) "geophysical classification" of glaciers into temperate, sub-polar and high-polar types; the "facies classification" addresses areal variations on a glacier rather than just the latitudinal aspect (Benson, 1959, 1961, 1967; Fig.
1C). Paterson (1981) presented a schematic diagram of glacier "zones", combining various aspects of the Benson (1959) and Müller (1962) concepts (Fig. 1D). Figure 1A-E shows the evolution of the glacier facies concept by Benson (1959, 1961, 1967), Müller (1962) and Benson and Motyka (1979).

Figure $1 \mathrm{~F}$, a modified composite of Figure $1 \mathrm{~B}$ and $\mathrm{E}$, presents the various elements of the glacier-facies concept as defined by Benson and Motyka (1979) and Müller (1962), and modifications suggested in this paper. Figure $2 \mathrm{~A}$ is a schematic cross-section of a valley or outlet glacier, or the margin of an idealized ice cap or ice sheet. Figure $1 G$ is a general schematic and Figure $2 \mathrm{~B}$ is a schematic cross-section of a valley or outlet glacier showing the relationship of reflectance measurements from satellite sensors to glacier facies.

\section{PREVIOUS WORK}

Early analysis of MSS imagery revealed at least two distinct, spectrally similar regions on many valley glaciers. When images are acquired during the melt season, it is usually easy to see the transient snow line that divides the regions; and, if the imagery is acquired at the end of the melt season, the snow line often corresponds quite closely with the equilibrium line.

Østrem (1975) and Østrem and Haakensen (in press) established a multiple-year relationship between fieldmeasured mass balance and the equilibrium-line altitude 
(ELA) obtained from satellite images for a few glaciers in Norway that established a straight-line function relating ELA to glacier mass balance for each glacier. When the position of the satellite-derived equilibrium line was plotted on topographic maps, the ELA was established and the mass balance for that year determined by reference to the pre-established curve. Thus, it may be possible to determine mass balance of a glacier directly from the position of the ELA as determined on satellite images.

Landsat imagery of an outlet glacier, Merkurjökull of the Mýrdalsjökull ice cap, Iceland, was studied by Crabtree (1976), and he found a reflectivity boundary up-glacier from the transient snow line that he attributed to the wet-snow line, above which he assumed that the percolation facies could be seen. As indicated below, the wet-snow line depends on wetting of the entire annual unit. Because surface snow and the upper part of the annual unit are wet above this line, the wet-snow line as a defined facies boundary cannot be located on Landsat images which see only the surface.

Williams (1987), using a digitally processed and enhanced Landsat MSS image of the Vatnajökull ice cap in Iceland acquired on 22 September 1973 (at about the end of the balance year), was able to delineate the firn line for the $8300 \mathrm{~km}^{2}$ ice cap (Björnsson, 1980a; Williams, 1983a) and to subdivide some of the facies on the basis of spectral reflectances. The ice facies, the transient snow line, the slush zone and the combined wet-snow/percolation facies could be differentiated. Vatnajökull is a temperate ice cap with no dry-snow facies (written communication from H. Björnsson, 1986; personal communication from H. Björnsson, 1989); information in this paper will serve to correct a previous erroneous interpretation by Williams (1983b, 1986a, b, 1987) of the presence of a dry-snow facies on Vatnajökull.
On a glacier, one usually find a continuum of grainsizes, the smallest being at the highest elevations, where temperatures are lower and the least amount of melting occurs, and the largest being just above the snow line. Theoretical calculations (Dozier and others, 1981) have shown that within the spectral regions covered by TM bands $5(1.55-1.7 \mu \mathrm{m})$ and $7(2.08-2.35 \mu \mathrm{m})$ which are in the middle-infrared part of the electromagnetic spectrum, there is greater sensitivity to snow grain-size than in the visible and near-infrared bands. Thus, there is potential for distinguishing the boundaries between facies using TM data in the middle-infrared part of the spectrum, if the surface grain-size distribution on a glacier can be characterized.

Employment of some TM band combinations has been shown to enhance surface features on certain glaciers (Hall and others, 1987; Orheim and Lucchitta, 1987). The use of the ratio of TM band $4(0.76-0.90 \mu \mathrm{m})$ to TM band $5(1.55-1.75 \mu \mathrm{m})$ has been employed for delineating spectrally similar regions and also in separating the ablation area from the adjacent morainal material (Hall and others, 1987). The ratio of TM band 4 to TM band 5 produces an image that enhances snow-and-ice features because of the large difference in spectral response in these features between TM band 4, where reflectance is often high over ice and snow, and TM band 5, where digital reflectance is low over snow and ice. Contrast enhancement is especially useful in the accumulation area of the glaciers, where the difference between the TM band 4 and 5 spectral response is the greatest (Hall and others, 1989).

\section{LANDSAT TM SPECTRAL REFLECTANCE CHARACTERISTICS OF BRÚARJÖKULL, ICELAND: A CASE STUDY}

Iceland's four largest ice caps, Vatnajökull $\left(8300 \mathrm{~km}^{2}\right)$,

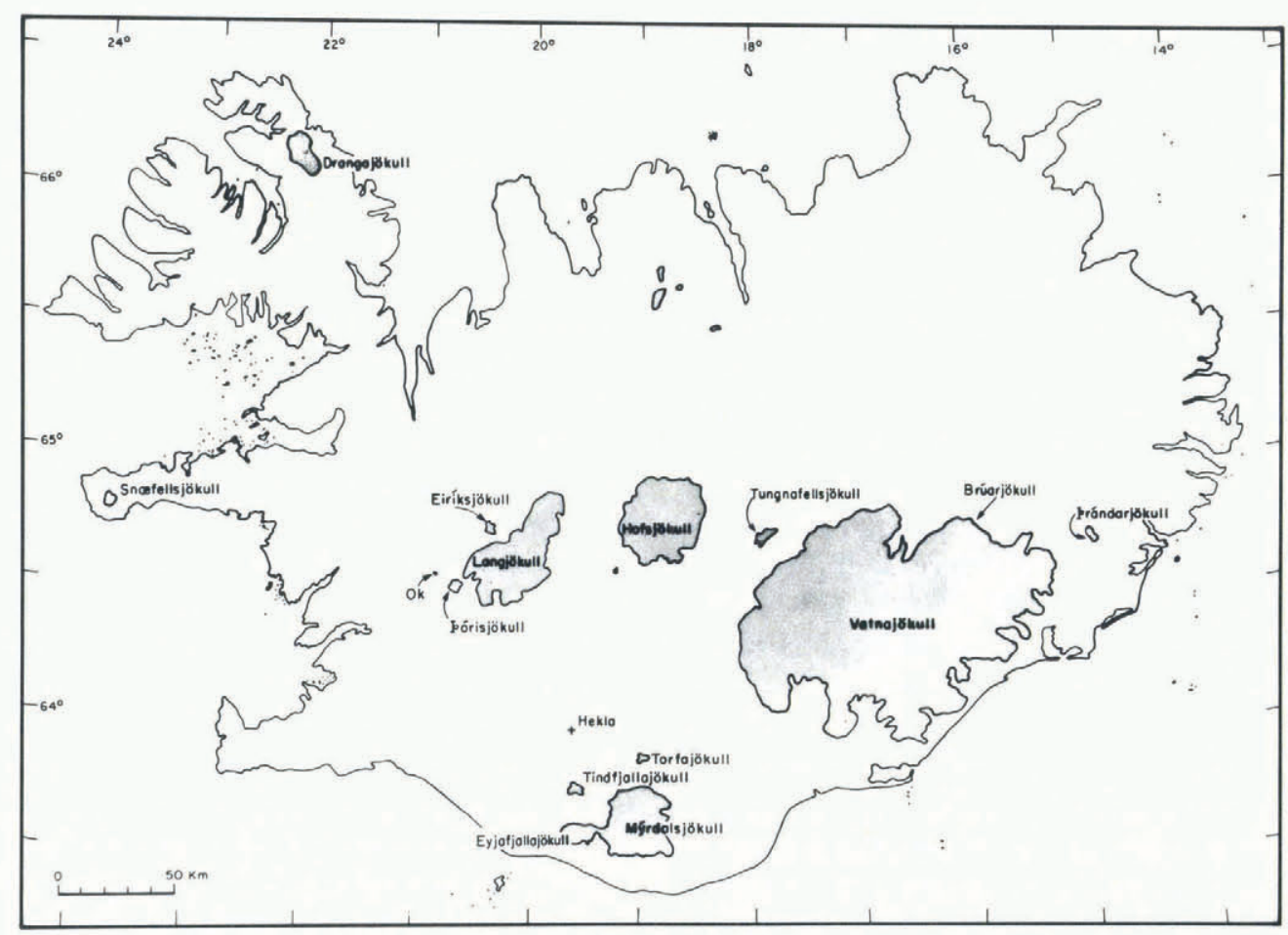

Fig. 3. Index map of Iceland showing locations of Hofsjökull, Hekla, Vatnajökull and Brúarjökull (map modified from Williams (1983a)). 


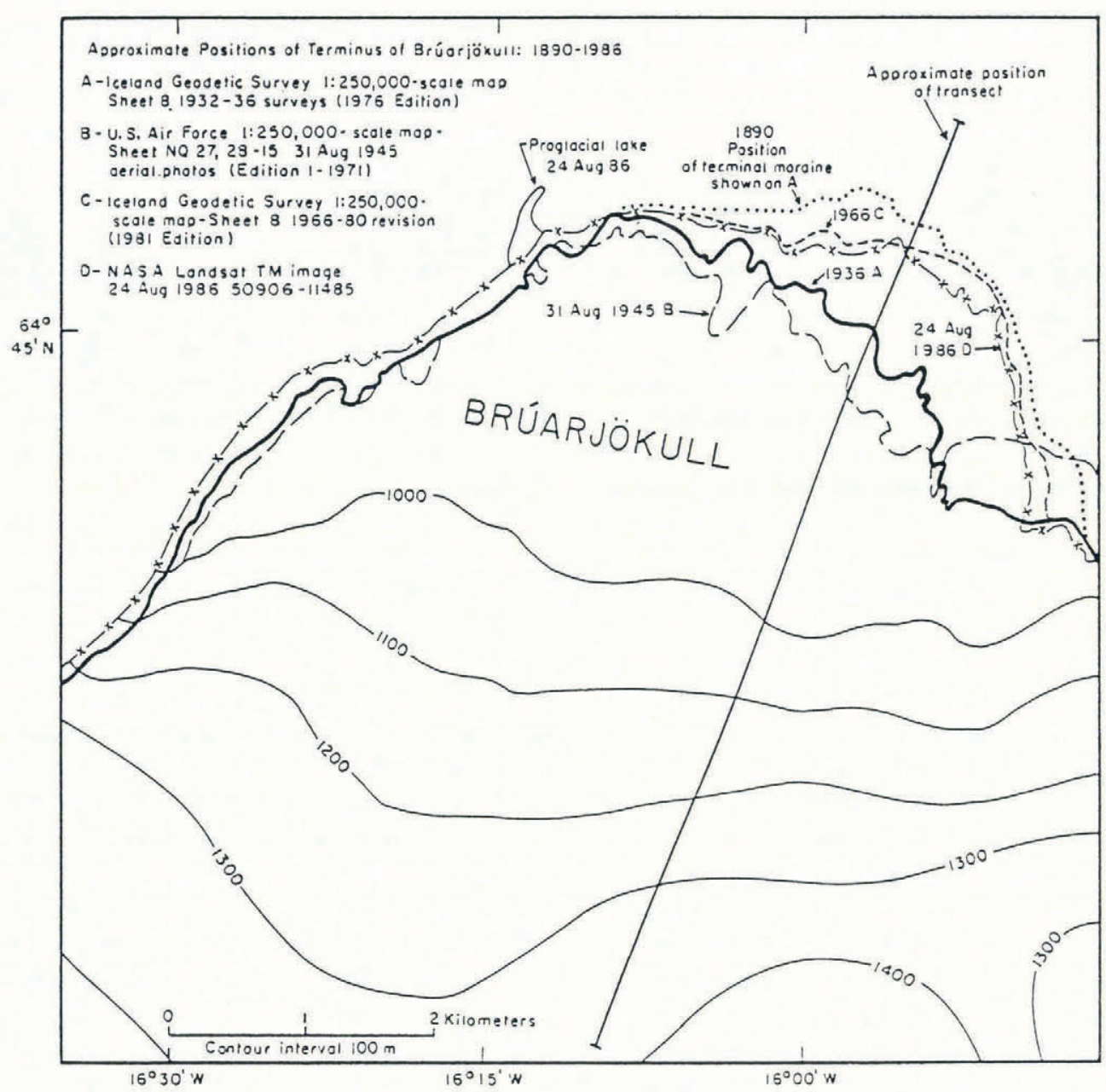

Fig. 4. Topographic sketch map of Brúarjökull, a lobate surging outlet glacier on the northern margin of the Vatnajökull ice cap (positions of terminus determined from the 1:250000 scale General Map Series of Iceland sheet 8 (1976 and 1981), Iceland Geodetic Survey, the 1:250000 scale Joint Operations Graphic (Ground) map sheet NQ 27, 28-15 of Iceland (1971), U.S. Air Force, and Landsat TM image 50906-11485 (24 August 1986)). Also shown is the approximate position of the transect shown on Figure 6.

Langjökull $\left(953 \mathrm{~km}^{2}\right)$, Hofsjökull $\left(925 \mathrm{~km}^{2}\right)$ and Mýrdalsjökull $\left(596 \mathrm{~km}^{2}\right)$, each have a number of broad, lobate outlet glaciers (Björnsson, 1980a, b). Figure 3 is an index map showing the location of Brúarjökull, a broad (about $40 \mathrm{~km}$ wide), surge-type outlet glacier on the northern margin of Vatnajökull. Brúarjökull, one of 38 named outlet glaciers of Vatnajökull (Williams, 1987), has had a long history of repetitive surge behavior; the greatest known historical surge was about $10 \mathrm{~km}$; in 1963-64, it surged $8 \mathrm{~km}$ (Thorarinsson, 1964, 1969). In Figure 4, the margin (terminus) of Brúarjökull is shown in different positions on three topographic maps, because the maps were compiled at different times in the glacier's surge cycle. The approximate margin of Brúarjökull, based on analysis of the 24 August 1986 Landsat TM image (5090611485), is also shown (Fig. 5), as well as the position of the transect along which spectral reflectance values were determined (Fig. 6).

The sloping rise of Brúarjökull (approximately $16.5 \mathrm{~m} \mathrm{~km}^{-1}$ ) and the broad area of the outlet glacier make it an ideal target for measuring spectral differences quantitatively from the terminus to the accumulation area. Brúarjökull also provides a small-scale analogy with the western margin of the Greenland ice sheet, where the concept of glacier facies originated.
Figure 5 is part $(1536 \times 1536$ pixels $)$ of a ratioed band $4 /$ band 5 Landsat TM image (50906-11485; 24 August 1986) of Brúarjökull showing the position of the northeast-southwest transect across morainal deposits, ice facies, transient snow line, slush zone, slush limit and snow facies. Figure 6 is a plot of TM bands 4 and 5 digital numbers along the transect line shown in Figures 4 and 5. Note the change, above and below the $0^{\circ} \mathrm{C}$ line, between wet snow and frozen snow of the snow facies that is evident on the TM band 5 transect (Fig. 6). The extreme reflectance variability of the TM band 4 data, especially in the debris-laden ice down-glacier from the transient snow line is not evident in TM band 5. Thus, a TM band $4 / 5$ image as seen in Figure 5 permits some of the glacier facies and boundaries between them to be delineated quite clearly. The TM band $4 / 5$ ratio enhanced the delineation of a boundary that appears to define the highest elevation of a region of wet snow at the surface in the snow facies. Up-glacier is a frozen surface of the snow facies. This upper boundary, where the air temperature was $0^{\circ} \mathrm{C}$, is not evident on the TM band 4 data but is visible as a subtle boundary when the TM band 5 data are analyzed.

Also on Figure 5, the location of selected topographic contours on Brúarjökull are shown. Note that the upper limit of the wet snow corresponds approximately with the 


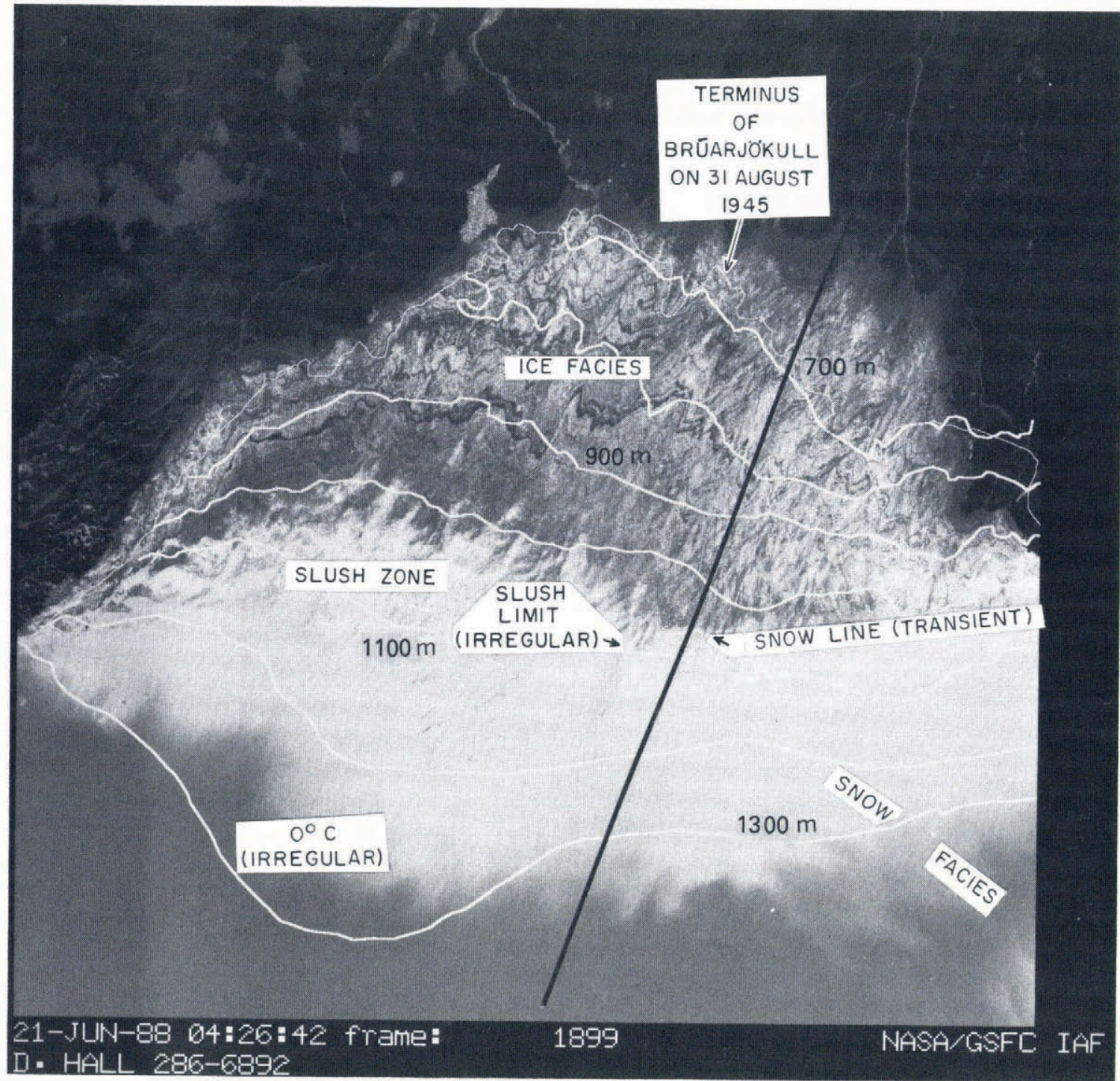

Fig. 5. Part of a Landsat thematic mapper (TM) ratioed band 4/band 5 image (50906-11485; 24 August 1986; $1536 \times 1536$ pixels) of Brúarjökull showing morainal deposits, ice facies, transient snow line, slush zone, slush limit (diffuse), snow facies (wet snow and frozen snow) and the approximate position of the transect (see Figs 4 and 5); approximate contour lines superposed from sheet NQ27, 28-15 (1971) and the margin of Brúarjökull on 31 August 1945 (outermost thin white line). Superimposed contour lines under $1000 \mathrm{~m}$ area unreliable because of changes in the outlet glacier over time.

$1300 \mathrm{~m}$ contour line. Meteorological records from Brú, a station located at an elevation of $360 \mathrm{~m}$ at $65^{\circ} 06^{\prime} \mathrm{N}$ and $15^{\circ} 32^{\prime} \mathrm{W}$ (about $40 \mathrm{~km}$ northeast of the terminus of Brúarjökull) were obtained by Magnús Már Magnússon (written communication, 1988) from Icelandic Weather Bureau records. The $0900 \mathrm{~h}$ Universal Time (UT) temperature at Brú for 24 August 1986 was $7.2^{\circ} \mathrm{C}$. If a lapse rate of $0.67^{\circ} \mathrm{C} / 100 \mathrm{~m}$ is used, the freezing level on Brúarjökull may be estimated to be located between 1300 and $1350 \mathrm{~m}$. According to the meteorologist Truasti Einarsson (cited in Magnús Már Magnússon's written communication, 1988), the freezing level from radiosonde data on 24 August 1986 was at 870 mbar, or 1300-1350 m. This level approximately corresponds with the upper reflectance boundary on the 24 August 1986 Landsat overpass at $1148 \mathrm{~h}$ UT (see Fig. 5).

The slush zone may be delineated on the surface of a glacier during the ablation season, being an area of varying width up-glacier from the transient snow line. It is completely saturated with water and grades up-glacier into the wet-snow facies. The different reflectance between the slush zone and the rest of the wet-snow facies in the visible spectrum is also apparent on TM band 4 (0.76$0.90 \mu \mathrm{m})$ but is not discernible on TM band 5 (1.55$1.75 \mu \mathrm{m}$ ) (Fig. 6). An ephemeral transition zone between the ice facies and the snow facies is herein defined as the slush zone (an integral part of the snow facies).

The wet-snow line has no surface manifestation and must be located by field measurements that extend 5-10 m below the surface. The transient snow line and the slush limit can be determined at the surface during the ablation season. However, the location of the wet-snow line depends on wetting reaching to the bottom of the annual snow-accumulation increment. It cannot be seen at the surface, because the top part of the annual accumulation increment in the percolation facies becomes wet at altitudes above the wet-snow line. The dry-snow line, although conceptually discernible at the surface, depends 


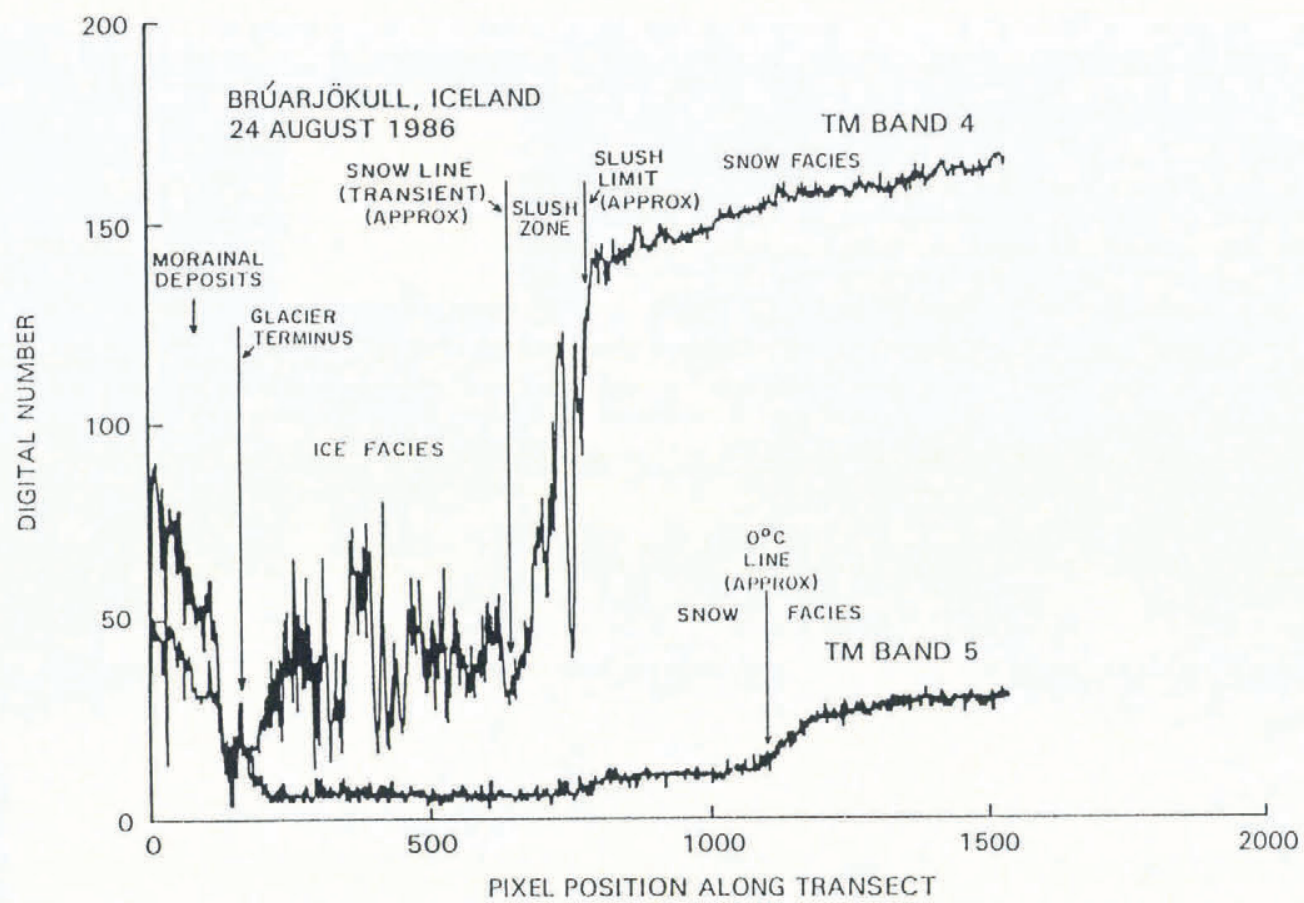

Fig. 6. Annotated spectral reflectance curves of TM bands 4 and 5 along the transect shown in Figures 5 and 6 . TM band 4 shows the sharp break between the ice facies and the snow facies. TM band 5 shows the subtle break between the slush zone and wet snow at the slush limit, and the sharp break between wet snow and frozen snow of the snow facies at the elevation on Brúarjökull where the air temperature was $0^{\circ} \mathrm{C}$ at $11.48 \mathrm{~h}$ UT on 24 August 1986. The digital number (DN) refers to the range of gray-scale increments recorded by each TM band, from 0 (black) to 255 (white).

on measurements which extend below the surface to show the presence or absence of slight wetting in several annual units. It is not as sharp a boundary as the wet-snow line and may be a transitional region about $20 \mathrm{~km}$ wide on the Greenland ice sheet

\section{SOME FACTORS WHICH COMPLICATE THE ANALYSIS OF SATELLITE IMAGES OF GLACIERS}

Many natural features on a glacier can obscure facies boundaries, such as a new snowfall and desert dust (Hall and others, 1987) and tephra from nearby volcanic eruptions, such as the 17 August 1980 eruption of Hekla, during which tephra was deposited on to Hofsjökull, Iceland, and was subsequently covered partially by a late summer snowfall (Landsat 2 MSS image 22044-12072; 27 August 1980). For example, Brown (1982) showed that a dark tephra layer deposited by the eruption of Mount St. Helens (18 May 1980) increased snowmelt by $40 \%$ at Paradise on Mount Rainier. Atmospheric effects may also influence the reflectance of snow and ice (Hall and others, 1990).

Analysis of remotely sensed data, without contemporaneous field observations, can often produce erroneous results. L. R. Mayo (written communication, 1989) noted that "A situation was found at Columbia Glacier [Alaska] (Mayo and others, 1979) that would have been impossible to interpret correctly with remote sensing data. ... Only once, under special lighting conditions, were we able to see the 1978 snow edge [sic, snowline], and took a special flight to document it. A Landsat image taken in 1978 would show a well defined snowline that was about $10 \mathrm{~km}$ down glacier from the equilibrium line."

An idealized glacier is one on which no new accumulation occurs after the ablation process begins. However, most glaciers do not follow this ideal pattern. The effects of accumulation and ablation are complex time-transgressive phenomena across the facies of a glacier (Mayo and others, 1972; Tangborn and others, 1977). Glaciers often receive summer snowfall and (or) rainfall that may mask boundaries on the lower part of a glacier, as observed from airborne or satellite platforms, and may interrupt the ablation season significantly (Mayo, 1963).

Mayo and Trabant (1986) carried out a series of observations of snow, new firn, old firn and glacier ice at three sites on Gulkana Glacier. They addressed problems caused by rain freezing on the glacier, which increases the surface reflectance recorded by TM band 4, while particulate matter on the surface reduces the reflectance. Such debris may also accentuate the distinction between the ablation and accumulation areas once melting begins, because the particulate matter darkens the surface. When new snow falls and then melts from the ablation area, the contrast between the ablation and accumulation areas is accentuated.

In addition, the glacier terminus, with its low reflectance caused by rock debris, can be so similar to the adjacent morainal and outwash-plain materials that it is difficult for MSS or TM data alone to give an accurate measure of the size of the ablation area. This has been discussed in Hall and others (1988), in which analysis of a 3 August 1984 TM scene of the Grosslockner glacier group in Austria did not reveal a reflectance boundary between 
the lower part of Pasterzegletscher and the snow line and slush limit.

\section{SUMMARY AND CONCLUSIONS}

Previous work has shown that one or more glacier facies are found on all glaciers and ice sheets. Landsat MSS or TM data have proven useful for the identification and measurement of the lower facies boundaries. The ability of the sensors to distinguish between different facies from satellite or airborne images is apparently due to snow grain-size differences. The near-infrared Landsat sensors have proven to be especially useful because of their sensitivity to grain-size. The gradual gradation to smaller grain-size up-glacier from the slush limit does not permit delineation of the wet-snow line as shown by an example on Brúarjökull, an outlet glacier from the Vatnajökull ice cap, Iceland. By superimposing the contour lines from a topographic map of Vatnajökull on to a part of a Landsat scene showing Brúarjökull, we were able to determine the approximate elevation where the air temperature was $0^{\circ} \mathrm{C}$ (freezing line on the outlet glacier). By extrapolation from a nearby meteorological station and from radiosonde data, the elevation was determined to be about $1300 \mathrm{~m}$ on 24 August 1986 at the time of Landsat image acquisition. The Landsat scene showed the upper limit of wet snow on that day.

The wet-snow line and the dry-snow line do not have surface manifestations and must be located by physical measurements that extend $5-10 \mathrm{~m}$ below the surface. The ice facies, transient snow line, slush zone, slush limit, wet snow and frozen snow can be delineated during the ablation season from Landsat TM digital data of Brúarjökull. On remotely sensed data we combine glacier ice and superimposed ice into an ice facies, and we combine wet-snow, percolation and dry-snow facies into a snow facies (Figs $1 \mathrm{G}$ and 2B).

\section{ACKNOWLEDGEMENTS}

The authors would like to acknowledge W. M. Kovalick for his expertise in image processing, E. P. Seginak for drafting support, L. M. Candler for typing, and L. R. Mayo and R. M. Krimmel for their comprehensive reviews. One of the authors (C.S.B.) was supported by Dr T. Moore, former President, University of Alaska, the U.S. National Science Foundation (grants DPP 79-26425 and DPP 9002345), NASA grant NAG 5-887 and the State of Alaska.

\section{REFERENCES}

Ahlmann, H.W. 1935. Contribution to the physics of glaciers. Geogr. 7., 86(2), 97-113.

Benson, C.S. 1959. Physical investigations on the snow and firn of northwest Greenland: 1952, 1953, and 1954. SIPRE Res. Rep. 26.

Benson, C. S. 1961. Stratigraphic studies in the snow and firn of the Greenland ice sheet. Folio Geogr. Dan., 9, 1337.
Benson, C. S. 1962. Stratigraphic studies in the snow and firn of the Greenland ice sheet. SIPRE Res. Rep. 70.

Benson, C. S. 1967. Polar regions snow cover. In Öura, H., ed. Physics of snow and ice. International Conference on Low Temperature Science ... 1966 ... Proceedings. Vol. 1. Part 2. Sapporo, Hokkaido University, 1039-1063.

Benson, C.S. and R.J. Motyka. 1979. Glacier-volcano interactions on Mt. Wrangell, Alaska. University of Alaska, Fairbanks. Geophysical Institute. Annual Report, 1977-78, 1-25.

Björnsson, H. 1980a. Glaciers in Iceland. Jökull 29, 1979, 74-80.

Björnsson, H. 1980b. The surface area of glaciers in Iceland. Fökull 28, 1978, 31.

Brown, B. E. 1982. Effect of ashfall on snowmelt rate at Paradise, Mount Rainer, Washington. 7. Geophys. Res., 87(C2), 1347-1350.

Crabtree, R. D. 1976. Changes in the Mýrdalsjökull ice cap, south Iceland: possible uses of satellite imagery. Polar Rec., 18(112), 73-76.

Dozier, J., S. R. Schneider and D. F. McGinnis, Jr. 1981. Effect of grain size and snowpack water equivalence on visible and near-infrared satellite observations of snow. Water Resour. Res., 17(4), 1213-1221.

Hall, D. K. J.P. Ormsby, R.A. Bindschadler and H. Siddalingaiah. 1987. Characterization of snow and ice reflectance zones on glaciers using Landsat Thematic Mapper data. Ann. Glaciol., 9, 104-108.

Hall, D. K., K. Bayr and W. M. Kovalick. 1988. Determination of glacier mass balance change using Thematic Mapper data. Proc. East. Snow Conf., 45th Annual Meeting, 192-196.

Hall, D. K., A. T. C. Chang, J. L. Foster, C. S. Benson and W. M. Kovalick. 1989. Comparison of in situ and Landsat derived reflectance of Alaskan glaciers. Remote Sensing Environ., 28, 23-31.

Hall, D. K., R. A. Bindschadler, J. L. Foster, A. T. C. Chang and H. Siddalingaiah. 1990. Comparison of in situ and satellite-derived reflectances of Forbindels glacier, Greenland. Int. F. Remote Sensing, 11(3), 493504.

Krimmel, R. M. and M.F. Meier. 1975. Glacier applications of ERTS images. J. Glaciol., 15(73), 391-402.

Mayo, L.R. 1963. 1961 meteorology and mass balance of Gulkana Glacier, central Alaska Range, Alaska. (M.S. dissertation, University of Alaska.)

Mayo, L. R. and D. C. Trabant. 1986. Recent growth of Gulkana Glacier, Alaska Range, and its relation to glacier-fed river runoff. U.S. Geol. Surv. Water-Supply Pap. 2290, 91-99.

Mayo, L. R., M.F. Meier and W. V. Tangborn. 1972. A system to combine stratigraphic and annual massbalance systems: a contribution to the International Hydrological Decade. 7. Glaciol., 11(61), 3-14.

Mayo, L. R., D. C. Trabant, R. March and W. Haeberli. 1979. Columbia Glacier stake location, mass balance, glacier surface altitude, and ice radar data, 1978 measurement year. U.S. Geol. Surv. Open-File Rep. 791168.

Meier, M. F. 1984. Contribution of small glaciers to global sea level. Science, 226(4681), 1418-1421.

Müller, F. 1962. Zonation in the accumulation area of the glaciers of Axel Heiberg Island, N.W.T., Canada. $\mathcal{J}$. 
Glaciol., 4(33), 302-311.

Orheim, O. and B.K. Lucchitta. 1987. Snow and ice studies by Thematic Mapper and multispectral scanner Landsat images. Ann. Glaciol., 9, 109-118.

Østrem, G. 1975. ERTS data in glaciology - and effort to monitor glacier mass balance from satellite imagery. $\mathcal{F}$. Glaciol., 15(73), 403-415.

Østrem G. and N. Haakensen. In press. Glaciers of Norway. In Williams, R. S., Jr and J. G. Ferrigno, eds. Satellite image atlas of glaciers of the world. U.S. Geol. Surv. Prof. Pap. 1386-E.

Paterson, W. S. B. 1981. The physics of glaciers. Second edition. New York, etc., Pergamon Press.

Tangborn, W. V., L. R. Mayo, D.R. Scully and R.M. Krimmel. 1977. Combined ice and water balance for Maclure Glacier, California, South Cascade Glacier, Washington, and Wolverine and Gulkana glaciers, Alaska, 1967 hydrologic year. U.S. Geol. Surv. Prof. Pap. 715-B.

Thorarinsson, S. 1964. Sudden advance of Vatnajökull outlet glaciers 1930-1964. Fökull 14, 76-89.

Thorarinsson, S. 1969. Glacier surges in Iceland, with special reference to the surges of Brúarjökull. Can. 7 . Earth Sci., 6(4), 875-882.
Wakahama, G., D. Kuroiwa, T. Hasemi and C. S. Benson. 1976. Field observations and experimental and theoretical studies on the superimposed ice of McCall Glacier, Alaska. F. Glaciol., 16(74), 135-149.

Williams, R.S., Jr. 1983a. Remote sensing of glaciers; geological applications. In Colwell, R. N., ed. Manual of remote sensing. Second edition. Falls Church, VA, American Society of Photogrammetry, 1852-1866.

Williams, R.S., Jr. 1983b. Satellite glaciology of Iceland. fökull 33, 3-12.

Williams, R.S., Jr. 1986a. Glacier inventories of Iceland: evaluation and use of sources of data. Ann. Glaciol., 8, 184-191.

Williams, R. S., Jr. 1986b. Glaciers and glacial landforms. In Short, N. M. and R. W. Blair, Jr, eds. Geomorphology from space. A global overview of regional landforms. Greenbelt, MD, National Aeronautics and Space Administration, 521-596. (Special Publication SP-486.)

Williams, R.S., Jr. 1987. Satellite remote sensing of Vatnajökull, Iceland. Ann. Glaciol., 9, 127-135.

The accuracy of the references in the text and in this list is the responsibility of the authors, to whom queries should be addressed. 